\title{
Linguistic Image of the Non-Christian Jews in Early Christian Narrative as a Function of Inter-Group Conflict (Text Analysis and Interpretation)
}

\author{
Amadeusz Citlak (iD) https://0000-0001-6550-1891 \\ Institute of Psychology \\ Polish Academy of Sciences \\ e-mail: acitlak@psych.pan.pl
}

\begin{abstract}
This article is an attempt to apply a psycholinguistic tools to reconstruct a linguistic image of the non-Christian Jews in chosen narratives taken from the Greek canonical Gospels of the New Testament. In this part of the analysis, Author uses the basic and empirically confirmed thesis of the linguistic category model and attribution processes, which are crucial when analysing the language of negative stereotypes.
\end{abstract}

Keywords: social psychology of religion, Jewish-Christian relations, anti-Judaism, stereotype, linguistic image of the world

Słowa kluczowe: społeczna psychologia religii, relacje żydowsko-chrześcijańskie, antyjudaizm, stereotyp, językowy obraz świata

In my earlier article, ${ }^{1}$ I presented the general characteristics of non-Christian Jews in the Gospel (Mark 11:27-12:40; Matthew 21:23-23:29; John 5:30-47; 7:14-36; $8: 31-59)$. I would now like to take a further step and analyse these narratives using the basic - yet empirically confirmed in contemporary social psychology of language - assumptions of the linguistic category model and attribution processes. In both cases, we can consistently analyse the language of religious stereotypes, as a result of which, it is also possible to compare different narratives with each other.

1 A. Citlak, Linguistic Image of the Non-Christian Jews in Early Christian Narrative as a Function of Inter-Group Conflict - Theoretical Background, "Studia Religiologica" 2019, vol. 52, no. 2, pp. $165-176$. 


\section{Actions of the characters and their traits}

The activity of the characters appearing in the narrative can be interpreted in many ways, but the focus here has been on a comparison and analysis of:

- verbal forms directly denoting actors' actions;

- adjectival forms denoting traits / attributes describing people;

- nominal forms relating to the method of categorising people and their actions.

In linguistic psychology, analysis of adjectives occurring in a discourse is very popular and has also gone through a number of theoretical and empirical studies. ${ }^{2}$ Perhaps this is because it can attribute trends used by participants of discourse to stereotypical perceptions of social world entities, especially when the relationship between the members of the groups in conflict is considered. An important indicator of the way of thinking about a social world is also the linguistic identification of actions on a continuum of morality (good, bad) vs. efficiency (smart, efficient, strong). In these three cases, adjectival forms are considered as an indicator of stereotypical thinking (negative or positive). Verb forms, however, are found much less frequently in linguistic optics, although it should be noted that they may also be an important indicator of such thinking. Research using linguistic category models is known in psychological literature ${ }^{3}$ which is based on three categories of verbal statements denoting different levels of abstraction describing the activities of a person. These are descriptive action verbs (describing single/individual activities), interpretive action verbs (describing complex actions) and state verbs describing internal states (such as feelings, experiences, emotions, etc.). ${ }^{4}$ This model reflects linguistic trends - and the specific tendencies behind them - towards a specific approach to the world, such as to move to a higher or lower level of abstraction $v s$. concreteness in describing someone's actions. This in turn results in a tendency to either stabilise or destabilise social knowledge. When describing members' negative behaviour of an opposing group narrative authors often have a tendency to move to a higher level of abstraction (stabilisation of negative beliefs) and the transition to a lower level of abstraction in the case of positive action description (destabilisation of positive beliefs and positive image). ${ }^{5}$ Description with a high level of abstraction significantly impedes the possibility of its negation or undermining, in contrast to a concrete level in which the subjects are usually single acts or events (e.g., John hit $v s$. John tortured).

A separate issue is the interpretation of the actors' actions in terms of their narrative purposes, e.g., whether the pursued objectives are positive, negative or neutral.

${ }^{2}$ A. Maas, M. Karasava, F. Politi, Do Verbs and Adjectives Play Different Roles in Different Cultures? A Cross-Linguistic Analysis of Person Representation, "Journal of Personality and Social Psychology" 2006, no. 90, pp. 734-750; G. Reeder, M. Brewer, A Schematic Model of Dispositional Attribution in Interpersonal Perception, "Psychological Review" 1979, no. 86, pp. 61-79.

${ }^{3}$ G. Semin, K. Fiedler, The Cognitive Functions of Linguistic Categories in Describing Persons: Social Cognition and Language, "Journal of Personality and Social Psychology" 1988, no. 54, pp. 558-568.

${ }^{4}$ The full model includes an additional fourth category, i.e., adjectives describing characteristic.

${ }^{5}$ G. Semin, K. Fiedler, The Inferential Properties of Interpersonal Verbs, [in:] Language, Interaction and Social Cognition, G. Semin, K. Fiedler (eds.), London 1992, pp. 58-78. 
As can be expected, although a simplification, in a situation of emergency and conflict between groups, both sides of the conflict should assign the opposing group negative goals and objectives, very rarely neutral, and very rarely positive. ${ }^{6}$ Finally, considering the actions of the actors, one can take into account the motivation attributed to them. In this case, attribution processes relate to methods of perceptual reasons of human behaviour. What is emphasised, especially in mainstream social cognition, are internal/external, variable/fixed and positive/negative attributions. ${ }^{7}$ Actor narrative can be perceived and described as an entity controlled by internal or external forces which remain under a variable or fixed influence. It is about a way of understanding other people which would allow an appropriate evaluation and classification to be made and to take appropriate actions. From the perspective of risk groups, for example, these processes were and are of paramount importance.

Presented below are the characteristics present in the gospel narratives:

a) attributions, i.e., the ways Christians explained and interpreted the Jews' behaviour and therefore at the same time attributed motivations to them which can be internal or external, in other words, whether they result from personal desires or the impact of external factors, whether they be positive/negative or constant/variable' (the last attributive aspect - constant/variable - being the most controversial and disputable in the gospel narratives);

b) authors' preferences of the narrative labelling of the Jews by assigning traits, and therefore using adjectival forms, while at the same time having a tendency to linguistically categorise the foreign group by using verb forms;

c) characteristics of the Jews' activity through appropriate verb forms used by Christian writers (here I refer to the linguistic category model by G. SeminK. Fiedler, although in a simplified form, i.e., only concentrating on verb forms, describing the internal states of the actors as the most significant and "diagnostic" verbs for identifying stereotypical thinking ${ }^{8}$ ). The authors' concentration on describing internal states of people, such as beliefs and feelings ("love" and "hate") and not for one-time activities like 'gone,' 'hit,' 'he said,' moves the discourse participants' attention to relatively constant personality dispositions and tendencies as well as suggests a certain behavioural stability of described entities.

${ }^{6}$ D. Bar-Tal, Conflicts and social psychology, [in:] Intergroup Conflicts and their Resolution: A Social Psychological Perspective, D. Bar-Tal (ed.), New York 2011, p. 1-38.

7 R. Brown, D. Fish, The Psychological Causality Implicit in Language, "Cognition" 1983, vol. 14, no. 3, pp. 237-273; H. Kelley, The Process of Causal Attribution, “American Psychologist" 1977, no. 28, pp. $107-128$.

${ }^{8}$ The full application of the model would require extensive analysis of language and their extensive presentation, which are not possible to contain in the size of this text (K. Collins, R. Clemens, Language and Prejudice: Direct and Moderated Effects, "Journal of Language and Social Psychology" 2012, vol. 31, no. 4, pp. 376-396). 


\section{a) Table 1. Chosen attribution of the non-Christian Jews' behaviour (Jewish motivation as perceived by Christians)}

\begin{tabular}{|c|}
\hline The Gospel of Mark 11:27-12:40 \\
\hline $\begin{array}{l}\text { fear and hypocrisy - negative / internal } \\
\text { greediness, desire to take over religious inheritance - negative / internal } \\
\text { desire "to catch Jesus in his words" - negative / internal } \\
\text { ignorance of the scriptures - negative / internal } \\
\text { illusory piety, greed, desire of adoration - negative / internal } \\
\text { exception: search for answers about the Greatest Commandment - positive / internal }\end{array}$ \\
\hline The Gospel of Matthew 21:23-23:29 \\
\hline 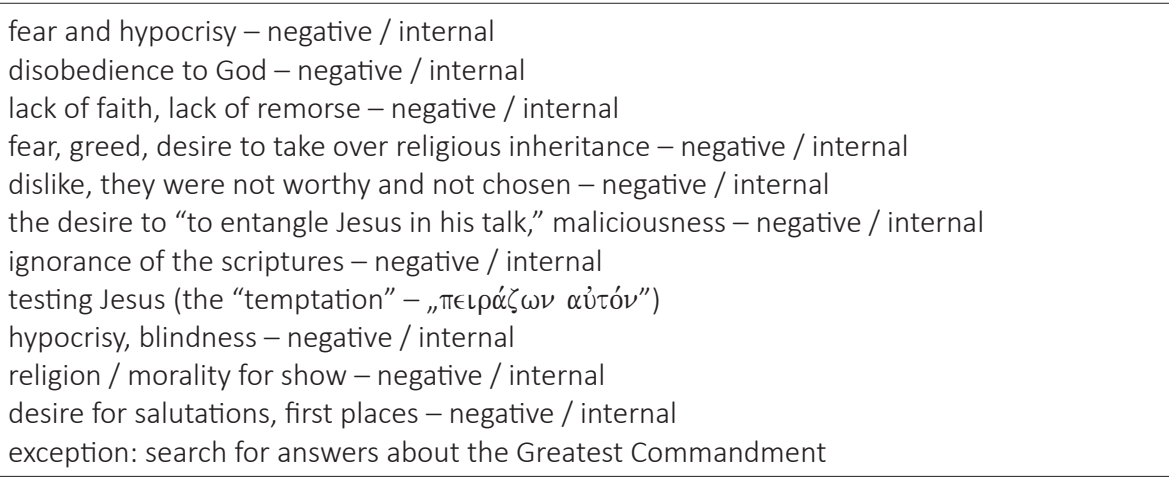 \\
\hline The Gospel of John 5:30-47; 7:14-36; 8:31-59 \\
\hline $\begin{array}{l}\text { 'unfaithfulness' to the word of God - negative / internal } \\
\text { searching for one's own glory - negative / internal } \\
\text { disbelief for the law of Moses - negative / internal } \\
\text { dislike for Jesus, to have eternal life - negative / internal } \\
\text { they did not accept Jesus because he came in the name of the Lord - negative / internal } \\
\text { "because the word of Jesus does not live in them"- negative / internal } \\
\text { the Jews want to kill Jesus because they do not know the Law of Moses - negative / internal } \\
\text { they do not believe because they do not know God - negative / internal } \\
\text { because they are not the children of Abraham - negative / internal } \\
\text { because they are not the children of God - negative / internal } \\
\text { they do not believe because Jesus speaks the truth to them - negative / internal } \\
\text { they do not believe because they are not from God - negative / internal } \\
\text { because they are children of the Devil - negative / internal } \\
\text { searching for eternal life - positive / internal } \\
\text { and also: } \\
\text { searching for eternal life - positive / internal } \\
\text { many believed in Jesus because they saw the miracles - positive / external } \\
\text { desire to experience joy - positive / internal }\end{array}$ \\
\hline
\end{tabular}

The summaries in the table above show an interesting profile of the Jewish environment. Although in subject literature, one's attention is turned numerous times to the cultural differences of the processes of attribution, ${ }^{9}$ here they are exceptionally

\footnotetext{
${ }^{9}$ R. Nisbett, Geography of Thought, New York 2003.
} 
unambiguous. Practically, in each of the three Gospels, the image of the non-Christian Jews is negative. The applied attributions are almost always linked to negative pursuits and negative motivations and what is more, they are internal attributions, i.e., the described characters of the narrative are guided by not so much external factors as the internal state of the heart or soul e.g., fear, desire for power, hypocrisy, disbelief. This state of things is imposed in an unambiguous manner. Also surprising seems the fact that by chronologically comparing the Gospel texts, the evolution of the perceived group threatening Christians can be seen. Just as in the example of the Gospel of Matthew, we are again faced with far-reaching modifications acquired from Mark's tradition. I have already mentioned this during the general text construction analysis, but here it seems visible on the level of attributions alone. Some steps are more subtle than others. An example of the first type is the motivation of the scribes' actions in "Mark" (pericope $3^{10}$ ) with the usage of the word $\dot{\alpha} \gamma \rho \in \dot{\omega} \omega$, which literally means an attempt at "catching"/“capturing" Jesus in his words, meanwhile in "Matthew" (pericope 5) the word used is $\pi \alpha \gamma\llcorner\delta \in \cup$ w, which already clearly indicates an attempt to entrap, or catch in the snare. "Matthew" at the same time, adds that their actions are the result of hypocrisy and malice (which is something "Mark" does not seem to know about). Similarly, in the case of clarifying those misguided scribes, in "Mark" (pericope 4) an explanation has been formulated in the form of a question proposed by Jesus, "Do not therefore err...?" But in "Matthew" (pericope 6), we are dealing with an indicator that here the narrator states an obvious fact that the scribes are mistaken for they know not the scriptures. "Matthew" emphasises the Jews' negative motivation even more strongly in his modification of their narrative on the Greatest Commandment (pericope 7). Mark's rabbi (pericope 5), a character assessed very positively by Jesus, becomes a negative figure in "Matthew" and what is more, this rabbi "puts Jesus to the test" - "tempting" him (the word $\pi \in \iota \rho \alpha ́ \zeta \omega$ also applied to the devil tempting Jesus in the desert). In the end, the whole passus completes a warning against the scribes and pharisees ("Matthew," pericope 9; "Mark," pericope 7). It is hard to find another assessment of such severity in any of the Gospels. "Matthew" expanded a brief warning against the scribes first contained in "Mark" to an unprecedented level describing the Jews as completely immoral. Their religious motivation is here reduced to hypocrisy and lies. In these two Gospels, one can see how far and in what direction the perception of the authors' narrative and linguistic image of this group shifted. This is testimony to a very dynamic and progressive conflict between Christians and Jews over the duration of just a few years of the $1^{\text {st }}$ century AD. The evolution of the perceived motivation can also be seen in the statement of synoptic tradition (i.e., "Matthew" and "Mark"), from the narratives of the Gospel of John. "John" repeatedly explains their lack of faith which is not about disbelief or so-called "little faith" but its lack of quality. The Jews simply don't believe: neither in God nor in Moses. Contrary to appearances, they do not come even from Abraham and have nothing to do with the God of Israel. The aspirations of the Jews are directed towards the capture and killing of Jesus - a motivation guiding them which is clearly negative. None of the previous Gospels represent the Jews as being in such strong opposition to Jesus. In "Mark"

${ }^{10}$ The references to pericopes relate to the article A. Citlak, Linguistic Image..., op. cit. 
and "Mathew" we see their hypocrisy, their misunderstanding of the Torah and their antagonistic attitude. "John," however, draws special attention to the inherent problem which is not so much the mutual incomprehension and hypocrisy of the Jews as it is their hostility to God and his messenger, Jesus. The key explanation of the Jews' attitude and behaviour is the final conclusion that they are the children of the devil who must fulfil his will and he is the main reason for their actions. The Jews do evil and wickedness because they cannot do otherwise. It is their devilish nature. The Jews do not believe in Jesus because "he told them the truth." These are two qualitatively different worlds: the Jews are on the opposing side and there is no chance of a mutual agreement. The drama of the situation is further emphasised by the fact that one of the narratives begins with the words that Jesus "spoke to those who believe in him" (8:31) and who are in the same narrative are they that work wickedness and

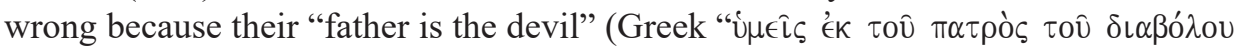
'́ơ $\tau$ '́" - 8:44a). Thus, even Jews who believe in Jesus, according to the author of John's narrative, really did not believe in him and in the end turned out to be his enemies.

\section{b) Table 2. Examples of usage of categories and attributes in the descriptions of the non-Christian Jews}

\begin{tabular}{|c|c|}
\hline $\begin{array}{l}\text { Attributes / traits } \\
\text { (adjectival forms) }\end{array}$ & $\begin{array}{c}\text { Category Assignment } \\
\text { (nominal forms) }\end{array}$ \\
\hline \multicolumn{2}{|r|}{ The Gospel of Mark } \\
\hline none & farmers, builders, hypocrisy, the kingdom of God \\
\hline \multicolumn{2}{|r|}{ The Gospel of Matthew } \\
\hline $\begin{array}{l}\text { evil, blind, unworthy, } \\
\text { foolish, dead }\end{array}$ & 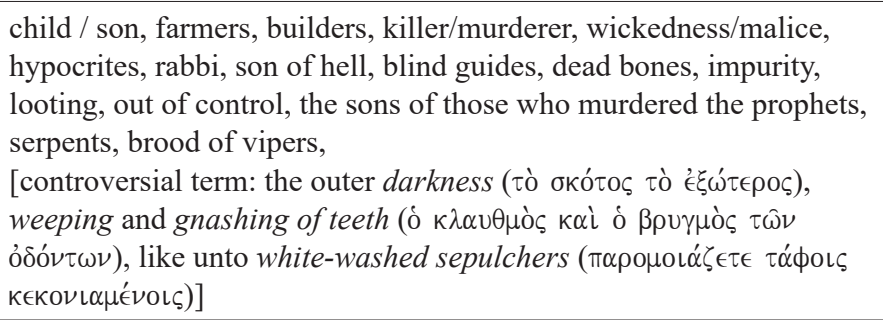 \\
\hline \multicolumn{2}{|r|}{ The Gospel of John } \\
\hline 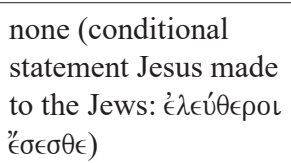 & 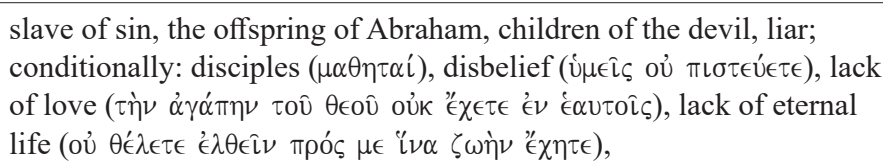 \\
\hline
\end{tabular}

On the basis of the above table, one can see that there is an evident change i.e., an intensifying negative assessment of the non-Christian Jews between the Gospel of Mark and the Gospel of Matthew. First, it concerns a proportionally greater quantity in the negative category in "Matthew." Second, the semantic weight of negative items is incomparably greater in "Matthew." Beyond that, "Mark" does not apply adjectival forms at all, i.e., he does not ascribe negative traits to the Jews through verbal labels. In contrast, using negative categorisation (a reference to the nominal forms), "Mark" 
only used the word "hypocrisy" once ( $\dot{\eta}$ úmókp thew are an extraordinary accumulation of pejorative categories, the weight of which is highlighted by multiple usage (e.g. "hypocrites").

It is difficult to determine to which extent negative image is further exacerbated in the Gospel of John. The semantic weight of Jesus' person seems more radicalised, mainly in comparison with the narratives of "Mark" (in "John," negative moral and religious categories of a stronger intensity are more frequently encountered). However, in comparison with the narrations of "Matthew," the Gospel of John does not seem to radicalise its evaluation in this respect. Attribution processes evident in the Gospel of John are primarily distinguished by a broader context of meaning, i.e. the fact that they are addressed to the entire nation of Israel and not only to groups of priests and scribes. In this respect, the negative evaluation of the Jews and assigning them to the negative category goes beyond the narratives of "Mark" and "Matthew" because their evaluations are of a more global nature.

A summary of adjectival and nominal categories, leads to an interesting conclusion about the evaluation process of social world entities in antiquity. Currently in mainstream social cognition research, the appeal of adjectival categories in descriptions and the labelling of social subjects is very common. Assigning features mainly occurs today through the use of adjectives since they denote moral and mental qualities or fitness. Much less commonly, modern man uses the whole breadth of characteristics in the form of general moral and religious categories such as good, evil, holiness and purity and therefore as a nominal category. Perhaps this results from the fact that in the history of cultural change, assessment processes have just become more sublime. But in contrast to the present, in the ancient world and at least in the context of the early Christians, a global evaluation was performed using mainly high moral and religious categories and not only characteristics. This way of thinking and its linguistic form generalised the appropriate image of the outside group. From the point of view of social psychology, in the case of a threatening group, it was a necessary treatment in some sense for the own protection and to take appropriate future strategic action. ${ }^{11}$ Surely, there should be a number of individual analyses on the linguistic representation of the social world in a variety of historical documents in order to answer questions about the source of such thinking, but not without significance remains the fact that even in the Gospel narratives, the adopted evaluation of the Jews is holistic and global. The authors of the narration do not focus much on assigning the threatening group individual negative traits but attribute to them a whole religious and moral category such as good, evil, condemnation, sin, impurity. ${ }^{12}$ This secured the aforementioned global assessment and justified taking swift and even violent defensive activities.

${ }^{11}$ H. Tajfel, J. Turner, An Integrative Theory of Intergroup Conflict, [in:] Psychology of intergroup relations, S. Worchel, W. Austin (eds.),Monterey 1979, pp. 33-47.

${ }_{12}$ A. Citlak, Spostrzeganie przestępców w warunkach zmiany społeczno-politycznej dawnego Izraela, "Studia Psychologiczne" 2007, vol. 45, no. 2, pp. 21-36; M. Kofta, Stereotype of a Group as-a-whole: The Role of Diabolic Causation Schema, "Polish Psychological Bulletin" 1995, vol. 26, pp. 83-96. 
c) Table 3. Focus on internal states of non-Christian Jews (perceived stability of behaviour):

\begin{tabular}{|c|c|}
\hline \multicolumn{2}{|c|}{ verbs describing the internal states of the non-Christian Jews } \\
\hline \multicolumn{2}{|r|}{ The Gospel of Mark } \\
\hline $\begin{array}{l}\text { The total number of verbs in } \\
\text { the studied text is } 57 ; 14 \text { of } \\
\text { these describe internal states } \\
(14 / 57=0.245)\end{array}$ & $\begin{array}{l}\text { we do not know; you did not believe; they insulted; they } \\
\text { feared; we know; they marvelled; } 2 \text { x you err; no one dared; } \\
\text { they want; they will respect; desiring; they feared; they knew; } \\
\text { ("you are not far from the Kingdom") }\end{array}$ \\
\hline \multicolumn{2}{|r|}{ The Gospel of Matthew } \\
\hline $\begin{array}{l}\text { The total number of verbs in } \\
\text { the studied text is } 118 ; 24 \text { of } \\
\text { these describe internal states } \\
(118 / 24=0.203)\end{array}$ & $\begin{array}{l}\text { they considered; we are afraid; we do not know; I do not } \\
\text { want; you did not believe; he repented; you did not regret; be- } \\
\text { lieve; they met; they feared; did not want to; they did not care; } \\
\text { they killed; you tempt; they amazed; you stray; you do not } \\
\text { know; they tempted; he could not; he did not dare; they did } \\
\text { not want to; they love; is exalted; you are; you did not want to }\end{array}$ \\
\hline \multicolumn{2}{|r|}{ The Gospel of John } \\
\hline $\begin{array}{l}\text { The total number of verbs in } \\
\text { the studied text is } 85 ; 27 \text { of } \\
\text { these describe internal states } \\
(27 / 85=0.317)\end{array}$ & $\begin{array}{l}\text { [controversial: if you remain / endure ( } \mu \epsilon i \nu \eta \tau \epsilon) \text {; you shall } \\
\text { know the truth }(\gamma \nu \omega \sigma \epsilon \in \theta \epsilon) \text {, you would love... }(\hat{\eta} \gamma \alpha \pi \hat{\alpha} \tau \epsilon)] \\
\text { you wanted; you do not have; you do not believe; it seems } \\
\text { to you; you have not; you do not believe; you do not accept; } \\
\text { you hope; you will; they marveled } 2 \mathrm{x} ; \text {, they wanted to kill } \\
\text { 2x; they are bitter; we know; you do not know; they tried to } \\
\text { capture; you cannot 2x; they believed; you not understand; } \\
\text { you are not able; you want to; you do not believe me 2x; you } \\
\text { dishonour; we know; you have not known }\end{array}$ \\
\hline
\end{tabular}

This summary of the proposed category of verb forms appears somewhat surprising because, both in terms of quantity and semantics, it is difficult to talk about clear linguistic changes in the description "outsider/stranger." The calculated quotients of verbs used to describe internal states (in the left-hand column of the table) obtain similar values in "Mark," "Matthew," "John" and the differences between them are not significant. ${ }^{13}$ In actuality, the second collection of narratives ("Matthew") includes a greater number of verb forms referring to states and emotions experienced. However, in proportion to the length of the text, the quantity does not fundamentally differ from the collection of "Mark's" and "John's" narratives. Such linguistic changes are somewhat different from the visual changes in adjectival and nominal uses. In accordance with Semin-Fiedler's assumed model, concentrating on the internal states (in this case "negative" states) should increase along with the deterioration of intergroup relations. Here, however, we do not see such a phenomena. It also needs to be taken into consideration that the model was used only in a simplified form and what

${ }^{13}$ To calculate the differences between the -quotients, a model based on the significant differences in proportions was used $/ \mathrm{z} />\mathrm{z}(\mathrm{a}=.05)=1.96$. There is practically no significant difference between them and they do not exceed $z>1.96$. The value of $z$ for the difference between The Gospel of Mark and The Gospel of Matthew is $z=0.5$; between The Gospel of Matthew and The Gospel of John, it is $z=1.41$; between The Gospel of Mark and The Gospel of John, it is $z=0.72$. 
is more, it was worked on by psychologists on the basis of a linguistic behaviour analysis at the end of the $20^{\text {th }}$ century. The results gained are testimony to the necessity to adapt the tools for research on ancient discourse. The summaries performed thus far are insufficient to draw unambiguous conclusions regarding tools alone. The fact remains, however, that their usage does not enable grasping the evolution of linguistic changes on this level. Despite this, we can see that in almost every narrative an important role plays concentration on the negative internal states of the Jews towards Christians, their hostility and even their desire to work towards their demise ("tempt," "insult," "kill," etc.) without any kind of information (with minor exceptions) about positive attitudes The states which the Jews experience can directly lead to acts of violence and aggression. In this respect, there is full compliance used in the description of verb categories with adjectives where the dominant negative forms are without adequate counterweight in the form of positive adjectives. Both the emotions experienced and the qualities possessed by the Jews show them as enemies and dangerous people for Christians.

\section{Summary}

The goal of this paper was to reconstruct relevant characteristics as well as eventual linguistic changes in the descriptions of non-Christian Jews. Firstly, it is an image relatively easy to open due to the strong conflict between the first Christians and the non-Christian Jews' environment. Secondly, this written discourse makes up, in this regard, a rich source of information which can be considered from various theoretical perspectives. Religious tension and antagonism systematically grows in strength in the $1^{\text {st }}$ century $\mathrm{AD}$, which probably built psychological atmosphere and mutual enmity, insecurity and reluctance. As we predicted, the image of the threatening group became an image that was increasingly negative and forcing Christians to take a more radical position and adopt appropriate protective action. What is more interesting, however, is that the Gospel narratives are characterised, regardless of the degree of increasing conflict, by negative assessment of the Jewish community which, at the end of successive years, steadily increases. This can be seen in the analysis of the structure of the gospel texts themselves. In the Gospel of Matthew, some positive content which occurs very early in the Christian tradition (primarily in the narrative of the Gospel of Mark) regarding the Jews disappears. Beyond that, new content appears in the Gospel of Matthew which places the Jews in a more adverse light. ${ }^{14}$ The narrative of the Gospel of John includes not only criticism of religious leaders, as is the case in the previous gospels, but extends the evaluation of the Galilean and Judean Jews to the whole Jewish society at that time. In other words, even behaviour desirable from the Christians' point of view, i.e. faith in Jesus, came to be interpreted as an act unworthy of trust. This image is also consistent with the attribution summary:

${ }^{14} \mathrm{Ph}$. Esler, Intergroup Conflict and Matthew 23: Towards Responsible Historical Interpretation of a Challenging Text, "Biblical Theology Bulletin" 2015, vol. 45, no. 1, pp. 38-59. 
Jewish motivation, actions and activities in relation to the first/primitive Christians and to Jesus are very often suspect of enmity and evil. ${ }^{15}$ The non-Christian Jews are guided by immoral motives and endeavours towards evil. After the fall of the Jewish uprising (70 AD), these descriptions (evident in the Gospel of Matthew and the Gospel of John) are characterised by a stronger polarisation in a negative direction. The Gospel of John shows them not only as enemies of the Christians but also as enemies of almost everything good, as well as being enemies of the sacred Torah and morality.

Interesting results are also provided in the table used in the narrative categories (nouns) and characteristics (adjectives) because they are not fully consistent with what is observed today in the process of social perception. This is especially true with regard to the domination and universality of adjectival forms and the denoting of characteristics which ultimately become part of diagnostic stereotypical thinking. Here, individual characteristics (adjectival forms) descend into the background as if they did not play a major role. To the fore of description stand out major categories, especially those of a moral and religious nature. They clearly dominate in each narrative set, especially in the Gospel of Matthew and the Gospel of John. This demonstrates using global judgments of those subjects and threatening the social world in the generally radical/unambiguous way of thinking. Christians of that time viewed the world from a religious point of view and anyone who denied their religious beliefs could find themselves not only in the category of "they" or "out-group" but also in the category of "enemy" or even of "evil" with the entire ballast of ensuing consequences. ${ }^{16}$ In our texts, the image of the non-Christian Jews is systematically deprived of positive behaviour and positive traits. This is also why the Gospel descriptions of the Jews are systematically characterised by some kind of negativisation until they finally become a tool in the hands of the Evil One. ${ }^{17}$ It is difficult on the basis of this short summary, however, to say whether this negativisation was a typical phenomenon of just the religious thinking or of ancient thinking in general as well. This would demand additional research to be conducted and the comparison of ancient sources. But there is no doubt that it was one of the important ways to deal with otherness or the threat of emerging group identity. From a psychological point of view, an enemy should not be positively assessed, even partially. Firstly, Christians did not make use of efficiency or competence assessments, which are typically used by the modern man, in the process of social cognition. ${ }^{18}$ Rather, they preferred moral assessments. This remains in accordance with a summary of verb forms from the linguistic category model, which is characterised by the constant presence of verbs

${ }^{15}$ N. Haslam, P. Bain, L. Douge, M. Lee, B. Bastian, More Human than You: Attributing Humanness to Self and Others, "Journal of Personality and Social Psychology" 2005, vol. 89, pp. 973-950.

16 J. Leyens, Psychological Essentialism and the Differential Attribution of Uniquely Human Emotions to Ingroups and Outgroups, "European Journal of Social Psychology" 2001, vol. 31, pp. 395-411; N. Haslam, P. Bain, L. Douge, M. Lee, B. Bastian, op. cit.; R. Gaunt, J. Leyens, S. Demoulin, Intergroup Relations and the Attribution of Emotions: Control over Memory for Secondary Emotions Associated with Ingroup or Outgroup, "Journal of Experimental Social Psychology" 2002, vol. 38, pp. 508-514.

${ }_{17}$ M. Kofta, op. cit.

${ }_{18}$ B. Wojciszke, Parallels between Competence - versus Morality - Related Traits and Individualistic versus Collectivistic Values, "European Journal of Social Psychology" 1997, vol. 27, pp. 245-256. 
referring to the enmity they experienced and a dislike of the Jews (although without a statistical difference in the time of the growing conflict). Diagnostic possibilities of the model should probably be tested entirely separately using all verbal and adjectival categories, ${ }^{19}$ although this would require a completely separate study. This would, I believe, enable a more complete analysis of linguistic changes in terms of the increasing tendency to use linguistic strategies responsible for stereotypical thinking. For the example shown, it can only create awareness of what kind of internal states were experienced by members of the described group.

In summary, one can say that early Christian Gospel discourse, besides clearly evolving, also shows characteristics of permanent stereotypical thinking. ${ }^{20}$ It is full of characteristics typical for groups in conflict and probably fulfilled a protective function for the status and survival of the given group - the Christian community. ${ }^{21}$ This image is extremely radical, all the more so because it can be opened on the basis of the Gospel canons and therefore on sources of great ethical value. However, this is an image that is completely understandable considering the (possible) presence of the psychological mechanisms occurring under conditions of group conflict. ${ }^{22}$ This was not, after all, an ordinary identity conflict. The non-Christian Jews not only rejected the followers of Jesus' religious interpretation of the Old Testament, but they made the decision to exclude them from the synagogue community in Jerusalem and the cities of Asia Minor at the end of the $1^{\text {st }}$ century AD (or earlier). ${ }^{23}$

In the $1^{\text {st }}$ century $\mathrm{AD}$, we can see Christianity emerging from Judaism, although the boundaries between them were quite fluid. Yet social assessments were radical from the very beginning of mutual tension. In my opinion, this is a form of antiJudaism, and R. Ruether, J. Isaac or W. Nicholls ${ }^{24}$ are not completely wrong in saying that this attitude is part of the early Christian tradition. However, the evaluation of this phenomenon should take into account the social realities of that time and should not be included in the framework of contemporary ethics. Radicalism was simply a typical feature of the ancient, religious world of Jews and the followers of Jesus.

19 A. Citlak, Problem nadróżnicowania językowego grupy własnej i obcej $w$ dokumentach historycznych, "Studia Psychologiczne" 2014, vol. 52, no. 2, pp. 40-57.

${ }^{20}$ J. Siker, Anti-Judaism in the Gospels According to Matthew, Mark, Luke, John, and Mel, "Pastoral Psychology" 2005, vol. 53, no. 4, pp. 303-312; J. Lamp, Is Paul Anti-Jewish? Testament of Levi 6 in the Interpretation of 1 Thessalonians 2:13-16, "The Catholic Biblical Quarterly" 2003, vol. 65, no. 3, pp. 408-427.

21 R. Hakola, Social Identities and Group Phenomena in the Second Temple Period, [in:] Explaining Early Judaism and Christianity: Contributions from Cognitive and Social Science, P. Luomanen, I. Pyysiäinen, R. Uro (eds.), Leiden 2007, pp. 259-276.

22 Idem, Social Identity and a Stereotype in the Making: The Pharisees as Hypocrites in Matt 23, [in:] Identity Formation in the New Testament. Wissenschaftliche Untersuchungen zum Neuen Testament 227, B. Holmberg, M. Winnige (eds.), Tübingen 2008, pp. 123-139; A. Kille, Psychological Dynamics of the Bible in Jewish/Christian Conflict, "Pastoral Psychology" 2005, vol. 53, no. 4, pp. $291-301$.

${ }^{23}$ It should be added that this image does not include all Jews (see Joseph of Arimathea or Nicodemus in the Gospel).

24 W. Nicholls, Christian Antisemitism: A History of Hate, Lanham 1995. 
This radical way of thinking is also found in other ancient documents ${ }^{25}$ and in the Old Testament against pagans. ${ }^{26}$ Luke Johnson also pointed out that the offensive language towards out-group members was typical in conflict situations, and anti-Jewish slander should be treated as a part of the conventions of ancient polemic. ${ }^{27}$

Invective was pervasive throughout the world of Mediterranean antiquity [...] It was expected that rivals would hurl insults against one another, and political leaders were proud, to some extent, of their ability to withstand brutal criticism and abuse [...] Thus invective was not particularly surprising or shocking; rather, it was an anticipated form of expression that the public noticed. ${ }^{28}$

The activation of such a stereotypical language was extremely easy, especially since it fulfilled a defensive function against the perceived threat.

Do the first Christian documents contain elements of stereotyping? In my opinion, yes. What is more, it is a natural phenomenon and a characteristic of written sources that arose in the conditions of inter-group tension or inter-group conflict, especially if the identity of the in-group was under threat. From the contemporary social psychology point of view, it can be said that the presence of stereotypic structures may indicate the authenticity of the examined documents and reveal their natural dynamics. ${ }^{29}$

These short conclusions are important for text interpretation and relevant in establishing the character of the text. How shall the gospel descriptions of the Pharisees or the Jews in general be treated in the $21^{\text {st }}$ century? Or the description of "foreign" and "heretics" in other New Testament books, for example, the Pauline letters? $?^{30}$ How shall the convictions of the first Christian writers be treated when they express their social views from the time when convictions came out of conditions of growing conflict? ${ }^{31}$ What should their status be in the history of Christianity or today in ecumenical dialog? At this stage of the analysis and at this point, I personally find it difficult to answer the above questions. Certainly, these texts require a broader theological or historical interpretation. We are dealing with documents not only expressing religious-theological views of (in this case) the first Christians, but also their radical worldview in psychological conflict. Such a far-fetched interpretation can be an exaggeration. But in many cases, we attempt to uncover the social-religious life or even simple events of a given groups; however, ancient history, unfortunately, has

${ }^{25}$ L. Johnson, The New Testaments Anti-Jewish Slander and the Conventions of Ancient Polemic, "Journal of Biblical Literature" 1989, vol. 108, no. 3, pp. 419-441.

${ }^{26}$ W. Brueggemann, Stereotype and Nuance: The Dynasty of Jehu, "The Catholic Biblical Quarterly" 2008, vol. 70, pp. 16-28; D. Macpherson, The Politics of Preaching the Promised Land for the Canaanites, "Political Theology" 2009, vol. 10, no. 1, pp. 71-84.

${ }^{27}$ L. Johnson, op. cit.

${ }_{28}$ A. Batten, The Letter of Jude and Graeco-Roman Invective, "HTS Teologiese Studies/Theological Studies" 2014, vol. 70, no. 1, p. 7.

${ }^{29}$ The problem, however, is primarily that "the psychological dynamics at play behind the shaping of the Christian identity and expressed in its scriptures reflect idealization of the in-group and progressive demonization of the out-group, and easily hook into similar dynamics in later communities and readers" (A. Kille, op. cit., p. 300).

${ }^{30}$ J. Lamp, op. cit., pp. 408-427.

${ }^{31}$ Ph. Esler, op. cit., pp. 38-59. 
only left us with a document written by their enemies. ${ }^{32}$ The use of psycholinguistics in conjunction with social cognition psychology creates new research possibilities though at the same time, opens a huge problem area that requires an interdisciplinary approach and a new research perspective. ${ }^{33}$ I think that the study of stereotypes in historical discourse should take into account the rich psychological tradition. This will allow not only a more precise analysis of the stereotypes, but also the chance to collect methodologically coherent empirical material that shows historical changes in social perception processes. Contemporary psycholinguistics offers a wide array of tools which allow the systematic accumulation of linguistic data, especially when used in the structural model. However, moving psycholinguistic findings to ancient and religious discourse requires great care and should take into account interdisciplinary co-operation (linguistics, psychology, theology, etc.).

\section{References}

Baker C., Early Christian Identity Formation: From Ethnicity and Theology to Socio-Narrative Criticism, "Currents in Biblical Research" 2011, vol. 9, pp. 228-237.

Baker C., Social Identity Theory and Biblical Interpretation, "Biblical Theology Bulletin" 2012, vol. 42, no. 3, pp. 129-138.

Bar-Tal D., Conflicts and social psychology, [in:] Intergroup Conflicts and their Resolution: A Social Psychological Perspective, D. Bar-Tal (ed.), New York 2011, pp. 1-38.

Batten A., The Letter of Jude and Graeco-Roman Invective, "HTS Teologiese Studies/Theological Studies" 2014, vol. 70, no. 1, pp. 1-7.

Brown R., Fish D., The Psychological Causality Implicite in Language, "Cognition” 1983, vol. 14, no. 3, pp. 237-273.

Brueggemann W., Stereotype and Nuance: The Dynasty of Jehu, "The Catholic Biblical Quarterly" 2008, vol. 70, pp. 16-28.

Citlak A., Linguistic Image of the Non-Christian Jews in Early Christian Narrative as a Function of Inter-Group Conflict - Theoretical Background, "Studia Religiologica" 2019, vol. 52, no. 2, pp. $165-176$.

Citlak A., Problem nadróżnicowania językowego grupy własnej $i$ obcej $w$ dokumentach historycznych, "Studia Psychologiczne" 2014, vol. 52, no. 2, pp. 40-57.

Citlak A., Spostrzeganie przestępców w warunkach zmiany społeczno-politycznej dawnego Izraela, "Studia Psychologiczne" 2007, vol. 45, no. 2, pp. 21-36.

Collins K., Clemens R., Language and Prejudice: Direct and Moderated Effects, "Journal of Language and Social Psychology” 2012, vol. 31, no. 4, pp. 376-396.

Esler Ph. Intergroup Conflict and Matthew 23: Towards Responsible Historical Interpretation of a Challenging Text, "Biblical Theology Bulletin" 2015, vol. 45, no. 1, pp. 38-59.

Explaining Christian Origins and Early Judaism: Contributions from Cognitive and Social Science, P. Luomanen, I. Pyysiäinen, R. Uro (eds.), Leiden 2007.

${ }^{32}$ R. Hakola, Social Identities and Group Phenomena in the Second Temple Period..., op. cit.

${ }_{33}$ C. Baker, Early Christian Identity Formation: From Ethnicity and Theology to Socio-Narrative Criticism. "Currents in Biblical Research" 2011, vol. 9, pp. 228-237; idem, Social Identity Theory and Biblical Interpretation, "Biblical Theology Bulletin" 2012, vol. 42, no. 3, pp. 129-38. 2007; Explaining Christian Origins and Early Judaism: Contributions from Cognitive and Social Science, P. Luomanen, I. Pyysiäinen, R. Uro (eds.), Leiden 2007. 
Gaunt R., Leyens J., Demoulin S., Intergroup Relations and the Attribution of Emotions: Control over Memory for Secondary Emotions Associated with Ingroup or Outgroup, "Journal of Experimental Social Psychology" 2002, vol. 38, pp. 508-514.

Hakola R., Social Identities and Group Phenomena in the Second Temple Period, [in:] Explaining Early Judaism and Christianity: Contributions from Cognitive and Social Science, P. Luomanen, I. Pyysiäinen, R. Uro (eds.), Leiden 2007, pp. 259-276.

Hakola R., Social Identity and a Stereotype in the Making: The Pharisees as Hypocrites in Matt 23, [in:] Identity Formation in the New Testament. Wissenschaftliche Untersuchungen zum Neuen Testament 227, B. Holmberg, M. Winnige (eds.), Tübingen 2008, pp. 123-139.

Haslam N., Bain P., Douge L., Lee M., Bastian B., More Human than You: Attributing Humanness to Self and Others, "Journal of Personality and Social Psychology" 2005, vol. 89, pp. 973-950.

Johnson L., The New Testaments Anti-Jewish Slander and the Conventions of Ancient Polemic, "Journal of Biblical Literature" 1989, vol. 108, no. 3, pp. 419-441.

Kelley H., The Process of Causal Attribution, “American Psychologist” 1977, vol. 28, pp. 107-128.

Kille A., Psychological Dynamics of the Bible in Jewish/Christian Conflict, "Pastoral Psychology" 2005, vol. 53, no. 4, pp. 291-301.

Kofta M., Stereotype of a Group as-a-whole: The Role of Diabolic Causation Schema, "Polish Psychological Bulletin” 1995, vol. 26, pp. 83-96.

Lamp J., Is Paul Anti-Jewish? Testament of Levi 6 in the Interpretation of 1 Thessalonians 2:13-16, "The Catholic Biblical Quarterly" 2003, vol. 65, no. 3, pp. 408-427.

Leyens J., Psychological Essentialism and the Differential Attribution of Uniquely Human Emotions to Ingroups and Outgroups, "European Journal of Social Psychology" 2001, vol. 31, pp. 395-411.

Maas A., Karasava M., Politi F., Do Verbs and Adjectives Play Different Roles in Different Cultures? A Cross-Linguistic Analysis of Person Representation, "Journal of Personality and Social Psychology" 2006, vol. 90, pp. 734-750.

Macpherson D., The Politics of Preaching the Promised Land for the Canaanites, "Political Theology" 2009, vol. 10, no. 1, pp. 71-84.

Nicholls N., Christian Antisemitism: A History of Hate, Lanham 1995.

Nisbett R., Geography of Thought, New York 2003.

Reeder G., Brewer M., A Schematic Model of Dispositional Attribution in Interpersonal Perception, "Psychological Review" 1979, vol. 86, pp. 61-79.

Semin G., Fiedler K., The Cognitive Functions of Linguistic Categories in Describing Persons: Social Cognition and Language, "Journal of Personality and Social Psychology" 1988, vol. 54, pp. 558-568.

Semin G., Fiedler K., The Inferential Properties of Interpersonal Verbs, [in:] Language, Interaction and Social Cognition, G. Semin, K. Fiedler (eds.), London 1992, pp. 58-78.

Siker J., Anti-Judaism in the Gospels According to Matthew, Mark, Luke, John, and Mel, "Pastoral Psychology" 2005, vol. 53, no. 4, pp. 303-312.

Tajfel H., Turner J., An Integrative Theory of Intergroup Conflict, [in:] Psychology of Intergroup Relations, S. Worchel, W. Austin (eds.), Monterey 1979, p. 33-47.

Wojciszke B., Parallels between Competence - versus Morality - Related Traits and Individualistic versus Collectivistic Values, "European Journal of Social Psychology" 1997, vol. 27, pp. 245-256. 